\title{
UPAYA PENINGKATAN AKTIVITAS DAN HASIL BELAJAR \\ MAHASISWA MELALUI MIND MAP DENGAN MODEL PEMBELAJARAN KOOPERATIF TIPE STAD PADA MATA KULIAH ANATOMI FISIOLOGI MANUSIA
}

\author{
Gustina Indriati, Evrialiani Rosba, Ria Kasmeri \\ Program Studi Pendidikan Biologi STKIP PGRI Sumatera Barat \\ Jln. Gunung Pangilun Padang-Sumatera Barat \\ e-mail: gustina_indriati@yahoo.com.
}

\begin{abstract}
Based on learning activities observation in human anatomy and fisiology major is low, like pay attention to the lecture, questioning, most of students talking each other, when they did the task the students more choose made in group. Activities learning of student is low because the students didn't have motivation in learning process, although the lecture has discution metode in learning process. The purpose of this research are to improve activities and student result of the learning. This research had used cooperative learning model with the type is STAD trough mind map in human anatomy and fisiology major. This research have been done to the students in STKIP. This research are action research that did in two phase. The phase are: Planning, doing, observation, and reflection. The data obtained through observation sheet documentation and test. Data that analysis from activities students and learning result of the students. The result of this research showed the improved of activities and learning result of the students. based on activities learning of student that get from cycluse 1 to the cycluse 2, showed that the increase of activities of the students like pre test (98\%) and post test $(100 \%)$ with very good category in cycluse 1 . In cycluse 2 become 5 activities like pre test (98\%), looking to the lecture (93\%), active to followed the discution (88\%), making mind map (90\%), followed post test (100\%) with very good category. Result of learning in cycluse 1 just 52\%, in cycluse 2 increased and become $83 \%$. Based on the result that been concluded using cooperative learning model type of STAD through mind map in human anatomy and fisiology major can increase activities and result learning of the students.
\end{abstract}

Kata kunci: Kooperatif STAD, Mind Map, Aktivitas, Hasil Belajar, Siklus

\section{PENDAHULUAN}

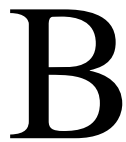

erdasarkan hasil observasi langsung pada mahasiswa semester VI Program Studi Pendidikan

Biologi STKIP PGRI Sumatera Barat Padang pada mata kuliah Anatomi
Fisiologi Manusia menunjukkan hasil yang belum memuaskan. Bila dilihat darisisi aktivitas mahasiswa masih belum menunjukkan antusiasme yang besar dalam pembelajaran Anatomi Fisiologi Manusia hal ini menyebabkan tidak teraktifkan potensi dan kemampuan maha- 
siswa secara maksimal, mahasiswa hanya sebagai pendengar akibatya mahasiswa cenderung pasif dalam kegiatan pembelajaran dikelas. Sehingga hasil belajar mahasiswa pada matakuliah Anatomi Fisiologi Manusia masih banyak yang terendah terlihat dari hasil tes yang dilakukan yaitu lebih dari $60 \%$ mahasiswa mendapat nilai Cdan D.

Melihat kondisi tersebut peneliti terdorong mengkaji berbagai aspek yang berkaitan dengan pembelajaran. Aspekaspek yang berkaitan dengan pembelajaran menunjukkan perlu adanya perbaikan pada teknik pembelajaran dan belajar yang selama ini dilakukan.Maka dari itu diperlukan adanya solusi yang tepat untuk perbaikan pembelajaran pada matakuliah Anatomi Fisiologi Manusia. Berdasarkan alasan tersebut, maka dilakukan penelitian tindakan kelas guna memperbaiki proses pembelajaran.

Penelitian Tindakan Kelas (PTK) merupakan suatu penelitian yang dilakukan secara sistematis reflektif terhadap berbagai "aksi" atau tindakan yang dilakukan oleh Dosen/pelaku, mulai dari perencanaan sampai dengan penilaian terhadap tindakan nyata di dalam kelas yang berupa kegiatan belajar-mengajar untuk memperbaiki kondisi pembelajaran (Arikunto, 2006).

Penelitian tindakan kelas dapat dilakukan dengan mengaplikasikan suatu model pembelajaran yang dapat membuat siswa menjadi aktif dan kreatif. Pembelajaran aktif merupakan suatu pembelajaran yang mengajak mahasiswa untuk belajar secara aktif. Belajar aktif mendominasi aktivitas pembelajaran sehingga siswa secara aktif menggunakan potensi otak, dalam hal menemukan ide pokok, memecahkan persoalan, atau mengaplikasikan apa yang baru dipelajari. Dengan belajar aktif, mahasiswa akan turut serta dalam proses pembelajaran sehingga mahasiswa dapat menikmati suasana yang lebih menyenangkan (Zaini dkk, 2004).
Salah satu pembelajaran yang mengoptimalkan potensi otak yaitu melalui mind map dan untuk meningkatkan aktivitas dan hasil belajar menggunakan salah satu model pembelajaran kooperatif tipe STAD yang melibatkan peran serta seluruh mahasiswa.Mind Map (peta pikiran) merupakan salah satu teknik mencatat tinggi yang tidak monoton karena memadukan fungsi kerja otak secara bersamaan dan saling berkaitan satu sama lain.

Student Teams-Achievement Divisions (STAD) merupakan salah satu model pembelajaran kooperatif yang paling sederhana dan merupakan model pembelajaran yang paling baik untuk permulaan bagi pendidik yang baru menggunakan model pembelajaran kooperatif (Robert E. Slavin, 2008). Dalam STAD, mahasiswa dibagi menjadi beberapa kelompok yang beranggotakan empat atau lima mahasiswa secara heterogen. Pendidik menjelaskan materi secara singkat dan kemudian di dalam kelompok itu memastikan bahwa anggota kelompoknya telah memahami materi tersebut setelah itu, semua mahasiswa menjalani kuis secara individu tentang materi yang sudah dipelajari. Skor hasil kuis mahasiswa dibandingkan dengan skor awal yang kemudian akan diberikan skor sesuai dengan skor peningkatan yang telah diperoleh mahasiswa. Skor tersebut kemudian dijumlahkan untuk mendapatkan nilai kelompok, dan kelompok yang bisa mencapai kriteria tertentu akan mendapatkan penghargaan.

\section{METODE PENELITIAN}

\section{Jenis Penelitian}

Jenis Penelitian yang dilaksanakan adalah Penelitian Tindakan Kelas (PTK) atau Classroom Action Research (CAR) yang dilakukan secara kolaboratif. Dosen dan peneliti mendiskusikan permasalahan penelitian dan menentukan rencana tindakan. Penelitian juga di- 
lakukan secara partisipatif, artinya peneliti dengan dibantu rekan satu tim matakuliah yang terlibat secara langsung dalam penelitian.

Penelitian dilakukan di STKIP PGRI Sumatera Barat semester enam dengan matakuliah Anatomi Fisiologi Manusia. Subjek penelitian ini adalah mahasiswa yang mengikuti perkuliahan Anatomi Fisiologi Manusia. Mahasiswa yang menjadi subjek penelitian yaitu mahasiswa Sesi A yang berjumlah 31 orang.

\section{Prosedur Penelitian}

Penelitian yang dilaksanakan ini terdiri atas dua siklus, dimana siklus dihentikan setelah melihat peningkatan aktivitas belajar mahasiswa sesuai dengan indikator yang diinginkan dan meningkatnya tes kemampuan mahasiswa dalam hal ini pemahaman konsep dan kemampuan pemecahan masalah. Secara garis besar setiap siklus terdiri atas 4 tahap, yaitu: perencanaan, tindakan, observasi/ pengamatan, dan refleksi.

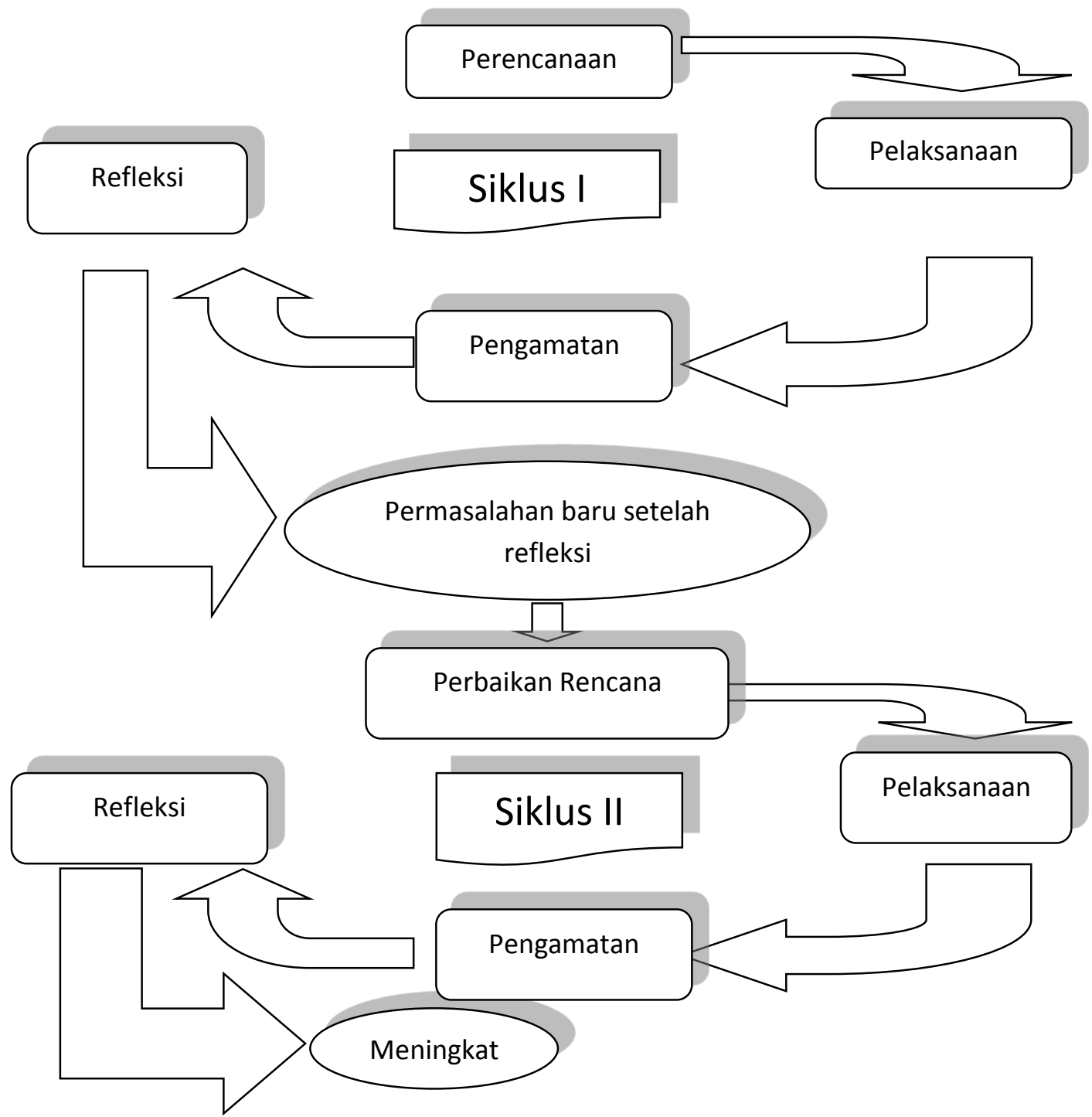

Gambar 1 : Siklus Penelitian (Arikunto, 2008 : 16) 


\section{Instrumen Pengumpulan Data}

Instrumen yang digunakan untuk mengumpulkan data dalam penelitian adalah sebagai berikut ini.

1. Lembar pengamatan aktivitas, digunakan untuk mengetahui aktivitas mahasiswa dan aktivitas dosen selama proses pembelajaran berlangsung.

2. Tes hasil belajar, digunakan untuk mendapatkan data yang diperlukan untuk melihat persentase pemahaman mahasiswa terhadap materi perkuliahan.

\section{Teknik Analisis Data}

1. Analisis pengamatan aktivitas mahasiswa

Sudjono (2004: 43) mengungkapkan bahwa untuk data hasil pengamatan dipakai ketentuan sebagai berikut:

$$
P=\frac{f}{N} X 100 \%
$$

Keterangan :

$\mathrm{P}=$ persentasi aktivitas yang dilakukan mahasiswa

$\mathrm{f}=$ jumlah mahasiswa yang terlibat di setiap aktivitas

$\mathrm{N}=$ jumlah mahasiswa yang hadir

Indikator keberhasilan untuk aktivitas belajar siswa secara klasikal adalah $75 \%$. Jika rata-rata aktivitas mahasiswa telah mencapai $\geq 75 \%$ berarti aktivitas mahasiswa dalam penerapan model pembelajaran kooperatif tipe STADmelalui Mind Map pada matakuliah anatomi fisiologi manusia sudah berhasil.

Tabel 1. Interval Aktivitas Mahasiswa

\begin{tabular}{cc}
\hline Interval Skor & Kategori \\
\hline $81-100$ & Sangat Baik \\
\hline $61-80$ & Baik \\
\hline $41-60$ & Cukup \\
\hline $1-40$ & Kurang \\
\hline
\end{tabular}

2. Analisis Hasil Belajar

Buku petunjuk penilaian hasil belajar mengungkapkan bahwa seorang mahasiswa dikatakan tuntas belajar apabila mendapat nilai $\geq 70$. Persentase ketuntasan individual dapat dihitung dengan rumus:

$$
N I=\frac{\mathrm{T}}{\mathrm{SM}} \times 100 \%
$$

Keterangan :

NI $=$ Ketuntasan belajar secara individual

$\mathrm{T}=$ Skor yang diperoleh mahasiswa

$\mathrm{SM}=$ Skor Maksimum dari tes

Sedangkan persentase ketuntasan belajar secara klasikal dapat dihitung dengan menggunakan rumus: $\quad N T=\frac{\mathrm{ST}}{\mathrm{N}} \times 100 \%$

Keterangan:

$\mathrm{NT}=$ Ketuntasan belajar secara klasikal

ST = Jumlah mahasiswa yang tuntas

$\mathrm{N}=$ Jumlah mahasiswa dalam satu kelas

Ketuntasan belajar secara klasikal apabila sudah $80 \%$ mahasiswa mencapai nilai ketercapaian yaitu $\geq 70$

\section{HASIL DAN PEMBAHASAN}

\section{Hasil Penelitian Siklus I}

\section{Aktivitas Mahasiswa}

Setelah dilakukan pengamatan selama proses perkuliahan menggunakan model pembelajaran kooperatif tipe STAD melalui Mind Map tentang aktivitas mahasiswa dirangkum dalam bentuk table dibawah ini. 
Tabel 2. Hasil Observasi Aktivitas Belajar Mahasiswa pada Siklus I

\begin{tabular}{cccccc}
\hline \multirow{2}{*}{ Aktivitas } & \multicolumn{3}{c}{ Pertemuan } & \multicolumn{2}{c}{ Rata-rata } \\
Persentase & \multirow{2}{*}{ Kategori } \\
\hline A.1 & I & II & III & 86 & Sangat Baik \\
\hline A.2 & 65 & 80 & 100 & 77 & Baik \\
\hline A.3 & 6 & 12 & 32 & 13 & Kurang \\
\hline A.4 & 9 & 16 & 22 & 15 & Kurang \\
\hline A.5 & 35 & 22 & 16 & 24 & Kurang \\
\hline A.6 & 38 & 68 & 77 & 61 & Baik \\
\hline A.7 & 39 & 45 & 74 & 53 & Cukup \\
\hline A.8 & 9 & 12 & 19 & 13 & Kurang \\
\hline A.9 & 100 & 100 & 100 & 100 & Sangat Baik \\
\hline A.10 & 38 & 51 & 64 & 51 & Cukup \\
\hline
\end{tabular}

Ket : A.I.1 = Aktivitas 1 dan Siklus 1

A.1 = Mahasiswa mengikuti pretest

A. 2 = Mahasiswa Memperhatikan penjelasan materi yang disampaikan dosen

A.3 = Mahasiswa mengajukan pertanyaan

A. 4 = Mahasiswa memberikan jawaban

A.5 = Mahasiswa ribut/ngobrol dengan teman sebelah ketika dosen menjelaskan materi

A.6 = Mahasiswa membuat mind map

A.7 = Mahasiswa aktif berdiskusi dengan kelompok

A.8 = Mahasiswa mempresentasikan hasil diskusi dalam bentuk mind map

A.9 = Mahasiswa mengikuti post tes

A.10 = Mahasiswa yang mendapatkan penghargaan dengan nilai kuis tinggi

Tabel 2 dapat menggambarkan peningkatan yang terjadi pada aktivitas belajar mahasiswa. Pada aktivitas A.1 pada pertemuan pertama, kedua dan ketiga mahasiswa mengikuti pretest, tetapi ada yang tidak mengikuti pada pertemuan pertama dan kedua karena terlambat masuk kelas. Aktivitas A.2 memperhatikan penjelasan materi yang disampaikan dosen, pada pertemuan pertama dan kedua masih ada mahasiswa yang kurang serius dalam mendengarkan penjelasan yang disampaikan dosen. Pada pertemuan ketiga mahasiswa sudah mulai serius mendengarkan penjelasan yang disampaikan dosen.

Aktivitas A.3 mengalami peningkatan dari pertemuan pertama ke pertemuan kedua yaitu dengan persentase $6 \%$, pada pertemuan kedua ke pertemuan ketiga meningkat menjadi $19 \%$ pada siklus I. Hal ini terjadi karena mahasiswa sudah mulai berani bertanya mengenai hal yang tidak dimengerti dalam perkuliahan.

Pada aktivitas A.4 pertemuan pertama, pertemuan kedua dan pertemuan ketiga mengalami peningkatan dengan persentase $6 \%$, hal ini karena mahasiswa banyak yang kurang berani mengemukakan pendapatnya dan karena tidak belajar sebelummya di rumah seperti yang ditugaskan dosen, sehingga tidak bisa menjawab pertanyaan ataupun menanggapi pertanyaan. Aktivitas A.5 pada pertemuan pertama ke pertemuan kedua mengalami pengurangan sekitar 4 mahasiswa dengan persentase $13 \%$, sedangkan pada pertemuan dua ke pertemuan ketiga mengalami pengurangan sekitar 2 mahasiswa dengan persentase $6 \%$ hal ini disebabkan karena dosen menegur ma- 
hasiswa yang mengobrol dan yang tidak memperhatikan.

Aktivitas A.6 yaitu membuat mind map, mahasiswa membuat mind map dengan bimbingan dosen dari pertemuan pertama sebanyak $38 \%$ ke pertemuan kedua mengalami peningkatan sebanyak $58 \%$ dengan selisih 20\%, sedangkan pertemuan dua sebanyak $58 \%$ ke pertemuan ketiga sebanyak $77 \%$ dengan selisih $12 \%$. Hal ini disebabkan karena masih ada mahasiswa yang belum mengerti cara membuat mind map. Aktivitas A.7 pada pertemuan pertama sekitar 38\%, pertemuan kedua sekitar $45 \%$ sedangkan pada pertemuan ketiga 78\%. Dari ketiga pertemuan tersebut terjadi peningkatan aktivitas mahasiswa dalam berdiskusi dalam kelompok. Hal ini disebabkan karena mahasiswa mulai merasa senang melakukan diskusi dan berbagi dengan anggota sesama kelompok.

Aktivitas A.8 pada pertemuan pertama $9 \%$, pada pertemuan kedua $12 \%$ dengan selisih 3\%, sedangkan pada pertemuan ketiga $19 \%$ selisihnya dengan pertemuan dua 7\%. Dari tiga kali pertemuan sudah terjadi peningkatan walaupun belum signifikan tapi hal ini sudah menunjukkan mahasiswa sudah ada keberanian untuk tampil kedepan kelas. Aktivitas A.9 mengikuti post tes/ kuis pada pertemuan pertama, kedua dan ketiga dengan persentase sama $100 \%$ hal ini disebabkan karena mahasiswa mengikuti semua untuk ujian. Aktivitas A.10 pada pertemuan pertama $38 \%$, sedangkan pertemuan dua $51 \%$ dengan selisih $13 \%$ dan pada pertemuan ketiga 64\% dengan selisih $23 \%$ dari pertemuan dua., walaupun terjadi peningkatan pada masing-masing pertemuan tapi masih ada mahasiswa yang mendapatkan nilai yang rendah.

Perkembangan aktivitas belajar mahasiswa pada materi system pencernaan (1), system pencernaan (2) dan system respirasi. Menggunakan model pembelajaran kooperatif tipe STAD melalui mind map pada mata kuliah Anatomi Fisiologi manusia dapat dilihat pada Gambar 2.

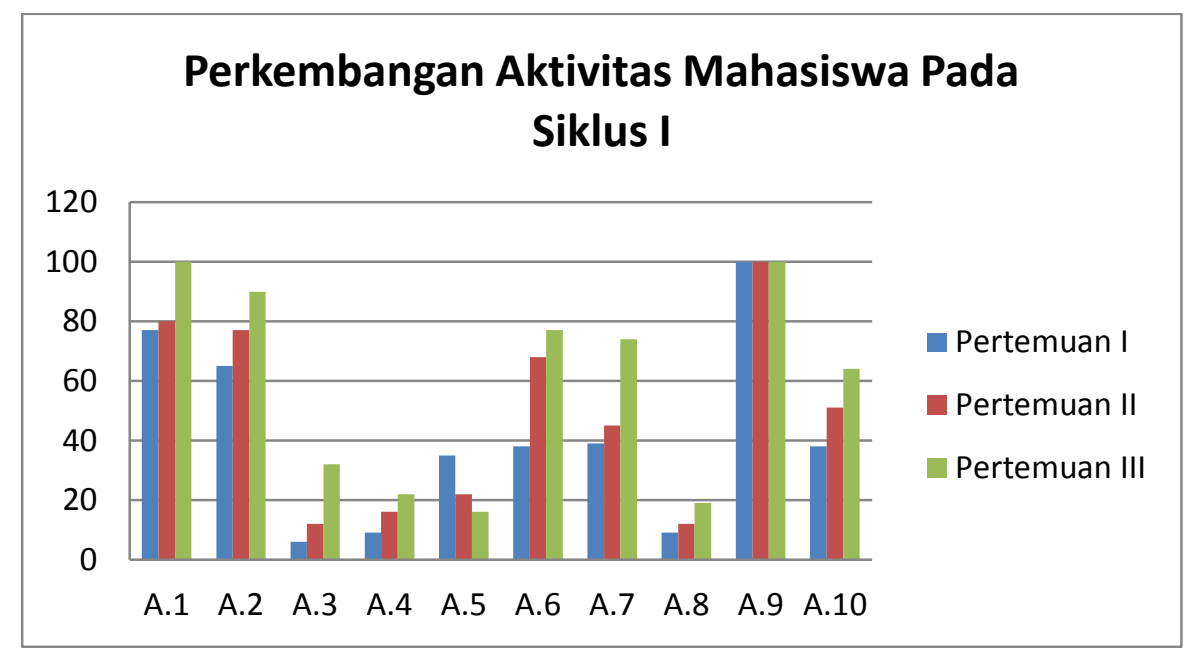

Gambar 2. Perkembangan Aktivitas Belajar Mahasiswa Menggunakan Model Pembelajaran Kooperatif tipe STAD melalui mind map pada Siklus I 
lebih menekankan kepada kemampuan mahasiswa berpikir secara individu dan berkerjasama secara berkelompok serta mampu aktif dalam pembelajaran, sehingga dapat meningkatkan hasil belajar mahasiswa. seperti yang terlihat pada Tabel 3.

Tabel 3. Ketuntasan hasil belajar mahasiswa pendidikan biologi pada mata kuliah anatomi Fisiologi Manusia siklus I

\begin{tabular}{cccc}
\hline Jumlah mahasiswa & Persentase $(\%)$ & Nilai & Kategori \\
\hline 16 & 52 & Adan B & Tuntas \\
\hline 15 & 48 & Cdan D & Tidak Tuntas \\
\hline $\begin{array}{l}\text { Ketuntasan } \\
\text { Klasikal }\end{array}$ & $52 \%$ & & \\
\hline
\end{tabular}

Dari Tabel 3 dapat kita lihat bahwa hasil belajar pada siklus I menunjukkan bahwa mahasiswa yang mencapai nilai diatas KKM sebanyak 16 orang atau $51 \%$ tuntas yaitu dengan rata-rata nilai $\mathrm{A}$ dan B dari 31 mahasiswa, sedangkan mahasiswa yang mencapai nilai dibawah KKM sebanyak 15 orang atau $48 \%$ belum tuntas yaitu dengan rata-rata nilai C dan D. Hal ini disebabkan selama mengikuti perkuliahan mahasiswa masih ada yang kurang serius dan tidak memperhatikan apa yang disampaikan dosen.

\section{Refleksi (Reflecting) Siklus I}

Berdasarkan hasil pengamatan peneliti terhadap pelaksanaan perkuliahan anatomi fisiologi manusia menggunakan model pembelajaran kooperatif tipe STAD menlaui mind map pada siklus I terdapat beberapa kelemahan. Berikut merupakan kelemahan dan rencana perbaikan yang akan dilaksanakan pada siklus II.

a. Refleksi Aktivitas Dosen Selama Perkuliahan Pada Siklus I

1) Dosen masih terfokus pada materi yang disampaikan, sehingga kurang memperhatikan mahasiswa

2) Dosen memberikan bimbingan pada beberapa kelompok saja, belum menyeluruh pada semua kelompok karena terbatasnya waktu
3) Dosen kurang memotivasi mahasiswa dalam diskusi kelompok, sehingga mahasiswa masih ada yang diam ataupun menjadi pendengar saja

b. Refleksi Aktivitas siswa Selama Pembelajaran Biologi Siklus I

1) Masih ada mahasiswa yang tidak memperhatikan dosen menyampaikan materi perkuliahan

2) Masih ada mahasiswa yang tidak aktif dalam diskusi, karena tidak mengerti dalam membuat mind map

3) Masih kurang keberanian mahasiswa dalam bertanya atau menjawab pertanyaan

Berdasarkan hasil refleksi pada siklus I, maka disusun rencana tindakan untuk siklus II dengan menitik beratkan perbaikan pada aktivitas aktif mengajukan pertanyaan, aktivitas menjawab pertanyaan, aktivitas berdiskusi, aktivitas mempresentasikan hasil diskusi, aktivitas membuat mind map.

\section{Hasil penelitian Siklus II}

\section{Aktivitas Mahasiswa}

Dasi hasil pengamatan yang dilakukan selama proses perkuliahan terhadap aktivitas mahasiswa dirangkum dalam bentuk Tabel 4 . 
Tabel 4. Hasil Observasi Aktivitas Belajar Mahasiswa pada Siklus II

\begin{tabular}{|c|c|c|c|c|c|}
\hline \multirow{2}{*}{ Aktivitas } & \multicolumn{3}{|c|}{ Pertemuan } & \multirow{2}{*}{$\begin{array}{l}\text { Rata-rata } \\
\text { Persentase }\end{array}$} & \multirow{2}{*}{ Kategori } \\
\hline & I & II & III & & \\
\hline A.1 & 96 & 100 & 100 & 98 & Sangat Baik \\
\hline A. 2 & 87 & 93 & 100 & 93 & Sangat Baik \\
\hline A.3 & 32 & 41 & 45 & 39 & Kurang \\
\hline A. 4 & 25 & 38 & 48 & 37 & Kurang \\
\hline A.5 & 6 & 6 & 3 & 5 & Kurang \\
\hline A. 6 & 83 & 90 & 97 & 90 & Sangat Baik \\
\hline A.7 & 80 & 87 & 97 & 88 & Sangat baik \\
\hline A. 8 & 22 & 29 & 38 & 29 & Kurang \\
\hline A.9 & 100 & 100 & 100 & 100 & Sangat Baik \\
\hline A.10 & 48 & 51 & 64 & 54 & Cukup \\
\hline
\end{tabular}

Ket : sama dengan pada siklus I

Tabel 3 dapat menggambarkan peningkatan yang terjadi pada aktivitas belajar mahasiswa. Pada aktivitas A.1 meningkat (86\%), akan tetapi masih ada yang tidak mengikuti karena terlambat masuk kelas. Aktivitas A.2 memperhatikan penjelasan materi yang disampaikan dosen, pada pertemuan pertama dan kedua masih ada mahasiswa yang kurang serius dalam mendengarkan penjelasan yang disampaikan dosen. Pada pertemuan ketiga sudah semua mahasiswa mendengarkan penjelasan yang disampaikan dosen dengan serius.

Aktivitas A.3 mengalami peningkatan dari pertemuan pertama ke pertemuan kedua yaitu persentase $9 \%$, sedangkan pada pertemuan kedua ke pertemuan ketiga 3\%. Hal disebabkan karena mahasiswa sudah mulai berani bertanya mengenai hal yang tidak dimengerti dalam perkuliahan.

Pada aktivitas A.4 pertemuan pertama dan pertemuan kedua meningkat (42\%) sedangkan pertemuan kedua dan ketiga (32\%), hal ini karena mahasiswa masih ada yang kurang berani mengemukakan pendapatnya. Aktivitas A.5 pada pertemuan pertama ke pertemuan kedua tidak mengalami pengurangan, sedangkan pada pertemuan dua ke pertemuan ketiga mengalami pengurangan sekitar 1 mahasiswa dengan persentase $3 \%$ hal ini disebabkan karena dosen menegur mahasiswa yang mengobrol dan yang tidak memperhatikan.

Aktivitas A.6 yaitu membuat mind map, mahasiswa membuat mind map dengan bimbingan dosen dari pertemuan pertama sebanyak $83 \%$ ke pertemuan kedua mengalami peningkatan sampai 90\%. Hal ini disebabkan karena mahasiswa sudah banyak yang mengerti cara membuat mind map. Aktivitas A.7 pada pertemuan pertama sekitar $80 \%$, pertemuan kedua sekitar $87 \%$ sedangkan pada pertemuan ketiga 97\%. Dari ketiga pertemuan tersebut terjadi peningkatan aktivitas mahasiswa dalam berdiskusi dalam kelompok. Hal ini disebabkan karena mahasiswa mulai merasa senang melakukan diskusi dan terbiasa.

Aktivitas A.8 pada pertemuan pertama $22 \%$, pada pertemuan kedua $29 \%$, sedangkan pada pertemuan ketiga $38 \%$ selisihnya dengan pertemuan dua. Dari tiga kali pertemuan sudah terjadi peningkatan aktivitas walaupun belum signifikan. Aktivitas A.9 mengikuti post tes/ kuis pada pertemuan pertama, kedua dan ketiga dengan persentase sama $100 \%$ hal ini disebabkan karena mahasiswa mengikuti semua untuk ujian. Aktivitas A.10 pada pertemuan pertama 
$48 \%$, sedangkan pertemuan dua $51 \%$ dengan selisih $3 \%$ dan pada pertemuan ketiga $64 \%$ dengan selisih $23 \%$ dari pertemuan dua., walaupun terjadi peningkatan pada masing-masing pertemuan tapi masih ada mahasiswa yang mendapatkan nilai yang rendah.
Perkembangan aktivitas belajar mahasiswa pada materi sistem eksresi, sistem reproduksi dan sistem panca indra. Menggunakan model pembelajaran kooperatif tipe STAD melalui mind map pada mata kuliah Anatomi Fisiologi manusia dapat dilihat pada Gambar 3.

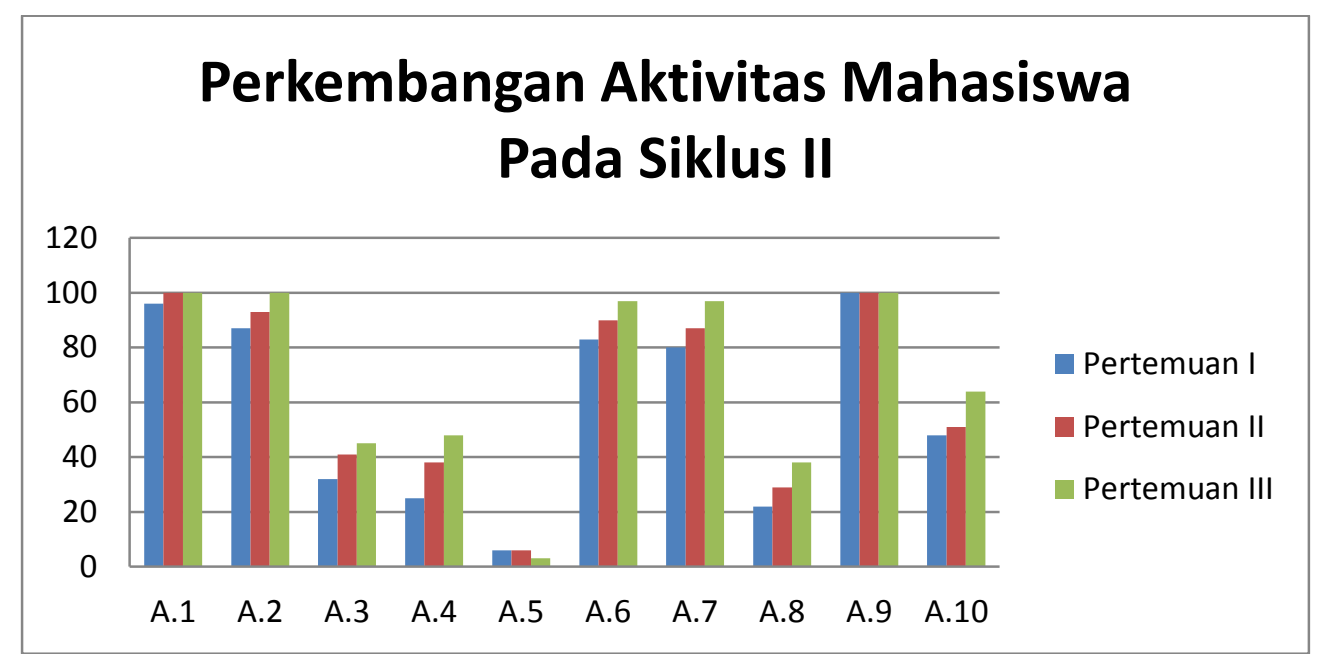

Gambar 3. Perkembangan Aktivitas Belajar Mahasiswa Menggunakan Model Pembelajaran Kooperatif tipe STAD melalui mind map pada Siklus II

\section{Hasil Belajar Mahasiswa}

Proses pembelajaran menggunakan model kooperatif tipe STAD melalui mind map pada matakuliah anatomi fisiologi manusia selain dapat meningkatkan aktivitas mahasiswa juga dapat meningkatkan hasil belajar mahasiswa, yang dapat dilihat pada tabel 5 .

Tabel 5. Ketuntasan hasil belajar mahasiswa pendidikan biologi pada mata kuliah anatomi Fisiologi Manusia siklus II

\begin{tabular}{cccc}
\hline Jumlah mahasiswa & Persentase $(\%)$ & Nilai & Kategori \\
\hline 24 & 77 & Adan B & Tuntas \\
\hline 7 & 23 & Cdan D & Tidak Tuntas \\
\hline Ketuntasan Klasikal & $77 \%$ & &
\end{tabular}

Dari Tabel 3 secara umum dapat di lihat bahwa hasil yang diperoleh mahasiswa dalam siklus II ini mengalami peningkatan yang sangat berarti sehingga melebihi nilai KKM yang telah ditetapkan. Mahasiswa yang tidak tuntas masih ada 7 orang atau $23 \%$ dari 31 mahasiswa. Hal ini disebabkan selama mengikuti perkuliahan mahasiswa masih ada yang kurang serius dan tidak memperhatikan apa yang disampaikan dosen.

Mahasiswa yang tuntas belajar pada siklus II yaitu sebanyak 25 orang atau $83 \%$. Hal ini menunjukkan bahwa materi yang disampaikan telah tuntas di kuasai mahasiswa. Bila dilihat dari presentase ketuntasan belajar yang diperoleh pada siklus I yaitu 52\% terlihat ada peningkatan sebesar $31 \%$. 


\section{Refleksi Siklus II}

Berdasarkan hasil pengamatan terhadap perbaikan pembelajaran yang dilakukan pada siklus II, masih terdapat beberapa kelemahan yang ada dalam proses pembelajaran berlangsung. Berikut merupakan kelemahan yang masih ada pada siklus II:

a. Secara umum proses pembelajaran pada siklus II telah dapat meningkatkan aktivitas dan hasil belajar bila dibandingkan dengan siklus I. Persentase yang dicapai pada siklus II juga lebih baik dibandingkan siklus I. akan tetapi masih ada yang perlu diperbaiki yaitu pada aktivitas bertanya, menjawab pertanyaan banyak juga yang malu atau tidak berani. Tapi untuk penelitian ini persentase pada masing-masing aktivitas ini sudah sesuai dengan taraf keberhasilan dari penelitian ini.

a. Hasil belajar siswa meningkat dari siklus I ke siklus II. Hal ini dapat dilihat dari jumlah siswa yang mencapai KKM pada siklus II lebih banyak dibandingkan dengan siklus I.

Berdasarkan temuan di atas, penelitian ini telah mencapai tingkat keberhasilan yang ditetapkan, sehingga tidak diperlukan tindakan pada siklus berikutnya.

\section{DAFTAR RUJUKAN}

Arikunto, Suharsimi. 2006. Penelitian Tindakan Kelas (PTK). Jakarta: Bumi Aksara

Hamalik, Oemar. 2004. Metode Belajar dan Kesulitan Belajar Mengajar. Bandung: Tarsito

Nana, Sudjana. 2009. Dasar-dasar Proses Belajar Mengajar. Bandung: Sinar Baru Algersindo.

Nana Syaodih, Sukmadinata. 2004. Landasan Psikologi Proses Pen-

\section{PENUTUP}

Terjadi peningkatan aktivitas belajar mahasiswa pada mata kuliah Anatomi Fisiologi Manusia akibat penerapan model pembelajaran kooperatif tipe STAD melalui mind map. Perbandingan aktivitas pada siklus I ada 2 aktivitas yang mencapai kriteria sangat baik yaitu indikator A.1 dan A.9, sedangkan pada siklus II ada 5 aktivitas yang mencapai kriteria sangat baik yaitu aktivitas A.1, A.2, A.6, A.7, A.9. Pada akhir siklus II semua aktivitas belajar mahasiswa sudah mencapai target yang telah ditetapkan.

Terjadi peningkatan hasil belajar mahasiswa pada matakuliah Anatomi Fisiologi Manusia akibat penerapan model pembelajaran kooperatif tipe STAD melaui mind map. Perbandingan hasil belajar pada siklus I persentase mahasiswa yang mencapai ketuntasan sebesar $52 \%$, sedangkan pada siklus II persentase siswa yang mencapai ketuntasan sebesar $83 \%$ dengan selisih perbandingan $31 \%$. Jika dilihat secara keseluruhan telah terjadi peningkatan hasil belajar pada siklus II hal ini sudah mencapai target yang telah ditetapkan.

didikan. Bandung: Remaja Rasda Karya

Rustaman. 2003. Strategi Belajar Mengajar Biologi Common Text Book Edisi Revisi. Jakarta: Universitas Negeri Indonesia

Sardiman, A.M. 2001. Interaksi dan Motivasi Belajar Mengajar. Jakarta: PT. Raja Grafindo.

Slameto. 2010. Belajar dan Faktorfaktor Yang Mempengaruhinya. Jakarta: Rineka Cipta. 
Slavin, E, Robert. 2010. Cooperatif Learning, Teori, Riset dan Praktik. Bandung: Nusa Media

Suyatno. 2009. Menjelajah Pembelajaran Inovatif. Sidoarjo: Masmedia Buana Pustaka
Syaiful, Sagala. 2005. Konsep dan Makna Pembelajaran. Bandung: Alfabeta. 